\title{
PENINGKATAN KUALITAS EKONOMI MELALUI USAHA MANDIRI (HOME INDUSTRY) DAN DAN SOSIALISASI PENCEGAHAN COVID - 19 DALAM MEWUJUDKAN KEHIDUPAN NEW NORMAL
}

\author{
Syaiful $^{1}$, Nur Aida Saraswati ${ }^{2}$ \\ ${ }^{1}$ Dosen Program Studi Akuntansi, Universitas Muhammadiyah Gresik. \\ ${ }^{2}$ Mahasiswa Program Studi Akuntansi, Universitas Muhammadiyah Gresik. \\ Email: syaiful@umg.ac.id
}

\begin{abstract}
ABSTRAK
Wabah COVID-19 telah dinyatakan sebagai pandemi oleh WHO sejak 11 Maret 2020. Penetapan itu didasarkan pada persebaran virus secara geografi yang telah mencapai 114 negara termasuk indonesia. Hal ini yang menjadi tujuan program Kuliah Kerja Nyata (KKN) Fakultas Ekonomi dan Bisnis Universitas Muhammadiyah Gresik kali ini, yaitu ikut terjun mensosialisasikan cara menanggulangi dan mencegah pendemi COVID-19 dan meningkatkanpendapatan ekonomi warga desa yang semakin menurun akibat akibat penyebaran COVID-19ini. Tema dari KKN ini yaitu Peningkatan Kualitas Ekonomi dengan Membuka Usaha SecaraMandiri (Home Industry) dan Sosialisasi Pembuatan Hand Sanitizer dan Cuci Tangan dengan Hand Shoap dalam Penanggulangan Penyebaran COVID-19 Melalui Media Sosial di Desa Ambeng-Ambeng Watangrejo Kec. Duduk Sampeyan Kabupaten Gresik. Metode yang digunakan adalah edukasi dengan menggunakan media Youtube, Aplikasi WhatsApp dan pamflet, pencegahan dan cara menanggulanginya serta penggunaan media sosial denganbijak. Juga diberi tambahan pengetahuan tentang cara Pembuatan Hand Sanitizer dan Cuci Tangan dengan Hand Shoap dengan benar. Dipilihnya metode ini, sebagai wujud social distancing saat berlakunya pembatasan sosial berskala besar (PSBB) di Kab Gresik. Pamflet ini ditempelkan di papan pengumuman warga. Hasil dari Kegiatan KKN dilihat dari antusias dalam aktif bertanya tentang edukasi dalam membuka usaha. Diharapkan dari kegiatan KKN ini, masyarakat di Desa Ambeng-Ambeng Watngrejo, Kec Duduk Sampeyan KabupatenGresik bisa lebih cerdas dalam memanfaatkan media sosial yang ada dan memahami tentang manfaat dari membuka usaha dan wabah COVID-19 cara mencegah dan menanggulanginya, dapat menjadi pemicu bagi jiwa kewirausahaan.
\end{abstract}

Kata kunci : home industry, Usaha Mandiri, covid-19, WHO, Pendemi, hand sanitizer, PSBB 


\section{DedikasiMU (Journal of Community Service)}

\section{PENDAHULUAN}

Organisasi kesehatan dunia (WHO) telah menetapkan virus corona COVID-19 dikategorikan sebagai pendemi pada tanggal 11 Maret 2020, di 114 negara.Istilah Pendemi menurut WHO adalah saat penyakit baru yang belum ada penawarnya menyebar di seluruh dunia lebih dari yang diperkirakan, mengutip the guardia oleh cnbcindonesia.com. COVID-19 adalah jenis virus corona baru yang pertama kaliditemukan di kota Wuhan, China pada bulan Desember 2019. Penyakit yang disebabkan oleh korona virus 2019 adalah penyakit menular yang disebabkan oleh virus SARS-CoV-2, salah satu jenis koronavirus (Gorbalenya, 2020). Penyakit ini telah mengakibatkan pandemi korona virus 2019-2020 (Hui DS, I Azhar E, Madani TA, Ntoumi F, Kock R, Dar O, lppolito G, Mchugh TD, Memish ZA, Drosten C, Zumia A, 2020).

WHO menyarankan cara pencegahan dan menggulangi dengan mencuci tangan dengan sabun, menjaga jarak dari orang saat bicara dan pada orang yang batuk, tidak menyentuh wajah dengan tangan yang tidak bersih. Juga disarankan untuk memakai masker serta menutup hidung dan mulut dengan tisu atau siku yang terketuk ketika batuk (https://www.who.int,2020b), (Chu et al.,2020), (Macintyre \& Wang,2020)

KKN merupakan suatu kegiatan perkuliahan intrakurikuler dalam bentuk pengabdian kepada masyarakat yang dilakukan mahasiswa secara interdisipliner dan lintas sektoral. Kegiatan ini ditujukan untuk mengembangkan kepekaan rasa dankognisi sosial mahasiswa serta membantu proses pengembangan bagian Integral dan proses Pendidikan.

Kegiatan KKN berisi rangkaian kegiatan pola hidup bersih dan sehat yangdikemas secara strategis untuk menyelesaian permasalahan secara tuntas dan dilaksanakan bersama masyarakat dengan memerankan masyarakat sebagai pelaku penting dan utama. Dalam hal ini, mahasiswa memiliki peran sebagai problem solving, fasilitator, koordinator, dan inovator dalam proses edukasi kepada masyarakat. Melalui konsep tersebut, kehadiran mahasiswa sebagai intelektual muda diharapkan mampu mengembangkan diri sebagai agen atau pemimpin perubahanyang secara cerdas dan tepat dalam menyelesaikan masalah yang dihadapi masyarakat.

Karena cukup berbahayanya pendemi COVID-19, dan tergolong virus baru dimana banyak masyarakat yang masih dalam kebingungan tentang virus ini, bagaimana cara pencegahan dan penanggulangannya. Pada dasarnya kegiatan yang dilakukan pada saat KKN merupakan bentuk pengabdian nyata kepada masyarakat dengan cara menyalurkan ilmu yang telah didapat selama perkuliahan sesuai bidang masing-masing. Mahasiswa memberikan edukasi berupa Poster, Video Animasi, Power point dan sebagainya untuk memberikan pengarahan agar dapat memecahkan masalah dan menanggulanginya secara tepat. Melalui KKN ini, mahasiswa membantu 


\section{DedikasiMU (Journal of Community Service)}

pembangunan dalam masyarakat/ pemberdayaan masyarakat sesuai dengan ilmu dan pengetahuan yang telah mereka dapat.

KKN dilaksanakan di Desa Ambeng-Ambeng Watangrejo Kecamatan Duduk Sampeyan Kabupaten Gresik. Desa Ambeng-Ambeng Watangrejo sendiri memiliki 3 Dusun, yang pertama yaitu Dusun Ambeng-Ambeng, yang ke-dua yaitu Dusun Watang, dan yang ke-tiga yaitu Dusun Dalemrejo. KKN kali ini bertempat di Dusun Ambeng-Ambeng. Kondisi keagamaan di Desa Ambeng-Ambeng Watangrejo adalah mayoritas Bergama islam yakni dengan menganut faham Nadhatul Ulama. Budaya masyarakat yang masih rutin dilakukan adalah kajian keagamaan. Wilayah Di Desa Ambeng-Ambeng sebagian besar merupakan dataran rendah dengan ketinggian antara 0-25 meter diatas permukaan air laut. Dengan temperatur suhu antara 20 derajat sampai dengan 35 derajat celcius. Desa Ambeng-Ambeng dilalui jalur pantura yang menguhubungkan Gresik dengan Lamongan. Sehingga jalur transportasi relatif padat, terutama dengan truk besar dan truk gandeng, arus lalu lintas tersendat, padat merayap, bahkan tidak jarang macetnya crowded.

Penularan virus COVID-19 yang semakin cepat membuat masyarakat harusdisiplin akan menerapkan protocol kesehatan. Maka dari itu disini mahasiswa melakukan sosialisi akan bahaya COVID-19 dan selalu mengingatkan masyarakat untuk selalu menerapkan protocol kesehatan dengan cara memakai masker ketika keluar rumah, hindari kontak fisik secara langsung, tidak lupa selalu mencuci tangan setiap atau setelah berpergian. Memberikan penyuluhan bagaimana mebuat handsanitizer dan cara mencuci tangan dengan baik dan benar.

Dan akibat dari adanya penyebaran COVID-19 yang semakin luas inimemyebabkan beberapa pendapatan dari keluarga desa menurun. Dengan mayoritas pekerjaan warga Dusun Ambeng-Ambeng adalah Petani Tambak. Dalam hal ini ibu rumah tangga yang hanya mengharapakan pendapatan yang diperoleh oleh suami. Membuka usaha sendiri dapat meningkatkan kualitas ekonomi ibu-ibu desa tanpa memberatkan suaminya. Maka dari itu, mahasiswa KKN menyelenggarakan kegiatan sosialisasi akan membuka usaha secara mandiri (Home Industry).

Menurut Sukirno (2011:331) "pertumbuhan ekonomi diartikan sebagai perkembangan kegiatan dalam perekonomian yang menyebabkan barang dan jasayang diproduksi dalam masyarakat bertambah dan kemakmuran masyarakat meningkat". Jadi pertumbuhan ekonomi mengukur prestasi dari perkembangan suatu perekonomian dari suatu periode ke periode lainnya. Kemampuan suatu negara untuk menghasilkan barang dan jasa akan meningkat. Kemampuan yang meningkat inidisebabkan oleh pertambahan faktor-faktor produksi baik dalam jumlah dan kualitasnya. Investasi akan menambah barang modal dan teknologi yang digunakan juga makin berkembang. Di samping itu, tenaga kerja bertambah sebagai akibat 


\section{DedikasiMU (Journal of Community Service)}

perkembangan penduduk seiring dengan meningkatnya Pendidikan dan keterampilan mereka. Secara umum, pertumbuhan ekonomi didefenisikan sebagai peningkatan kemampuan dari suatu perekonomian dalam memproduksi barang-barang dan jasa- jasa. Pertumbuhan ekonomi adalah salah satu indikator yang amat penting dalam melakukan analisis tentang pembangunan ekonomi yang terjadi pada suatu negara. Pertumbuhan ekonomi menunjukkan sejauh mana aktivitas perekonomian akan menghasilkan tambahan pendapatan masyarakat pada suatu periode tertentu. Karena pada dasarya aktivitas perekonomian adalah suatu proses penggunaan faktor-faktor produksi untuk menghasilkan output, maka proses ini pada gilirannya akan menghasilkan suatu aliran balas jasa terhadap faktor produksi yang dimiliki oIeh masyarakat (Basri, 2010), dengan adanya pertumbuhan ekonomi maka diharapkan pendapatan masyarakat sebagai pemilik factor produksi juga akan meningkat. Perekonomian dianggap mengalami pertumbuhan jika seluruh balas jasa riil terhadap penggunaan faktor produksi pada tahun tertentu lebih besar dari pada tahun sebelumnya. Dengan kata lain perekonomian dikatakan mengalami 12 pertumbuhan jika pendapatan riil masyarakat pada tahun tertentu lebih besar dari pada pendapatan riil masyarakat pada tahun sebelumnya.

\section{METODE PELAKSANAAN}

\section{Onlinisasi}

Kegiatan edukasi membuka secara mandiri ditujukan kepada ibu-ibu warga desa AmbengAmbeng. Peserta diberikan motivasi agar memiliki kemauan untuk membuka usaha secara mandiri (home industry) untuk meningkatkan kualitas ekonomi dan memberdayakan ekonomi kreatif, sehingga dapat lebih komersial bagi warga desa Ambeng-Ambeng Watangrejo. Selanjutnya kegiatan sosialisasi melalui kepada masyarakat warga desa Ambeng-Ambeng Watangrejo dalam pembuatan hand sanitizer, tutorial mencuci tangan dengan air yang mengalir dengan baik dan benardan pemberian soasialisasi akan bahaya COVID-19 kepada warga sekitar. Metode ini diambil karena Kabupaten Gresik dalam masa pembatasan sosial berskala besar (PSBB). Hasil kegiatan ini dilihat dari antusiasnya masyarakat dalam aktif bertanya pada saat sosialisasi atau edukasi diberikan

\section{Perencanaan Kegiatan}

Perencanaan kegiatan dapat dilakukan setelah pelaksanaan onlinisasi dilakukan. Tetapi perlu dilakukan survey apakah masih banyak ibu-ibu rumah tangga yangmenganggur di Dusun Ambeng-Ambeng

Agar program ini berjalan dengan lancer, maka perlu dilakukan perencanaan secara tepat misalnya :

1) Mengamati bagaimana tingkat ekonomi warga Dusun Ambeng-Ambeng 


\section{DedikasiMU (Journal of Community Service)}

2) Menyusun waktu pelaksanaan kegiatan

3) Mempersiapkan materi yang akan diberikan

4) Memberikan jawaban akan pertanyaan atau memberikan solusi masukan

3. Metode Pelaksanaan :

Program Wajib

1. Mahasiswa menyiapakan materi yang akan diberikan dalam pemberianedukasi membuka usaha mandiri (Home Industry)

2. Mahasiswa merekam materi yang disampaikan dan menguploadnya melalui media online youtube

3. Mahasiswa membagi link youtube ke grup whatsapp PKK Ambeng- Ambeng

4. Mahasiswa menjawab pertanyaan ibu-ibu yang kurang paham, bertanya tentang masalah dalam usaha mandiri atau masalah yang saat ini dimiliki oleh pelaku usaha (Home Industry)

\section{Teknik Pelaksanaan}

Pelaksanaan kegiatan Pengabdian Pada Masyarakat ini dilakukan dengan menggunakan metode tutorial dan diskusi. Adapun sismandiria pelaksanaan kegiatan pengabdian ini adalah sebagai berikut :

Langkah 1 (Metode Tutorial)

Ibu-Ibu diberikan materi membuka usaha secara mandiri (Home Industri), mengenai Penjelasan dari apa itu uasaha, cara membuka usaha, keuntungan membuka usaha, dan cara mempertahankan usaha.

Langkah 2 (Metode Diskusi)

Ibu-Ibu diberikan kesempatan untuk bertanya tentang keraguan yang mereka miliki sebelum memulai usaha atau permasalahan yang saat ini dimiliki oleh ibu-ibu pelaku usaha.

\section{Monitoring dan Evaluasi}

Monitoring dan eavluasi dilaksanakan untuk mengetahui perkembangan pelaksanaan kegiatan, dan menilai kesesuaian kegiatan yang telah dilaksanakan dengan perencanaan. Evaluasi dapat juga berfungsi sebagai motivator bagi ibu-ibu PKK desa Ambeng-Ambeng untuk memperbaiki perekonomian warga desa. Hasil yang dicapai yakni respon dari ibu-ibu PKK yang aktif bertanya dan juga saling memberikan solusi pada setiap pertanyaan atau permasalahan pada saat diskusi. Setiap usaha memiliki permasalahan yang berbeda-beda jadi untuk solusi yang diberikan pun berbeda juga. 


\section{DedikasiMU (Journal of Community Service)}

\section{HASIL DAN PEMBAHASAN}

Kegiatan dilakukan pada hari minggu, 9 Agustus 2020. Kegiatan ini dilaksanakan dengan cara bergabung dengan grup WhatsApp ibu-ibu PKK Dusun Ambeng- Ambeng dan melakukan survey berapa banyak ibu-ibu yang mengganggur dan bekerja. Di Dusun Ambeng-Ambeng kebanyakan ibu-ibu menganggur dan hanyamendapatkan pemasukan dari penghasilan suaminya sedangkan mayoritas kepala keluarga yang ada di Dusun Ambeng-Ambeng bekerja sebagai petani tambak. Dari survey yang di lakukan di grup PKK ambeng-Ambeng total sebanyak 10 ibu-ibu yang memiliki usaha, diantaranya $5 \mathrm{ibu}$-ibu yang membuka usaha toko sembako, $2 \mathrm{ibu}$-ibu yang berjualan rempah-rempah dan bumbu dapur, 2 ibu-ibu yang berjualan nasi dan 1 ibu yang berjualan sosis keliling, kemudian 12 ibu-ibu yang bekerja sebagai buruh pakrik dan 15 ibu-ibu yang menganggur.

Pada hari rabu, 12 Agustus 2020 selanjutnya dilakukan pemberian materi berupa powerpoint dalam bentuk video yang di upload di youtube dan membagikan link tersebut di grub PKK AmbengAmbeng, ibu-ibu memahami materi yang disampaikan pada video tersebut, dan selanjutnya di adakan sesi tanya jawab untuk menghilangkan keraguan dan rasa ketakutan ibu-ibu agar berani dalam memulai usaha dan mengambilkeputusan.

Dari pertanyaan ibu-ibu yang belum bekerja kebanyakan dari mereka bingung ingin memulai usaha apa dan bagaimana cara mendapatkan modal yang cukup untuk memulai usaha. Diberikan masukan serta penjelasan dalam memilih usaha, sebaiknya memilih usaha yang sesuai dengan potensi dan minat, pilih bisnis atau usaha yang sedang tren atau berkembang pada saat ini untuk memenuhi kebutuhan pasar. Sebenarnya modal bukanlah masalah besar dalam memulai usaha karna kita dapat mendapatkan modal yang biasannya ada dalam program pemerintah, pinjaman bank dan juga melakukan usaha gabungan dengan teman atau orang lain untuk menambah modal yang tentunya melalui kesepakatan bersama.

Selanjutnya untuk yang sudah bekerja atau memiliki pendapatan kebanyakan dari mereka adalah pemilik toko sembako yang memiliki masalah dalam usahanya dimulaidari hutang macet, barang yang expired dan daya beli masyrakat yang semakin rendah. Diberikan solusi atau jalan keluar untuk menyelesaikan masalah tersebut agar tidak merugikan pedagang, dan dapat memperlancar usaha dagangnya.

Kegiatan perekaman pembuatan Hand Sanitizer dilakukan pada hari minggu, 16 Agustus 2020, kegiatan dilakukan dengan terlebih dahulu mengumpulkan bahan dan juga alat pembuatan Hand Sanitizer dan mencuci tangan kemudian dibuat lah tutorial pembuatan Hand Sanitizer.

Kegiatan perekaman cara mencuci tangan dengan baik dan benar menggunakan air yang mengalir dilakukan pada hari senin, 17 Agustus 2020. Selanjutnya di meng upload video tutorial tersebut di youtube dan membagikan link youtube pembuatan 


\section{DedikasiMU (Journal of Community Service)}

Hand Sanitizer dan mencuci tangan tersebut ke masing-masing ketua rt dan grub ib-ibu PKK untuk disebarluaskan.

Hasil dari pembuatan Hand Sanitizer dan masker di bagikan kepada warga dengan cara menyalurkannya kepada dari masing-masing Ketua Rt di Dusun Ambeng- Ambeng dan untuk di salurkan kepada warga yang membutuhkan, sebanyak 20 Hand Sanitizer dan 50 Masker yang akan dibagikan kepada warga. Ketua Rt di Dusun Ambeng-Ambeng sangat antusias atas pemberian masker dan Hand Sanitizer yang diberikan. Selanjutnya dilakukan penempelan poster di papan pengumuman warga desa ambeng-ambeng, sebanyak 3 poster yang ditempel yang berisikan tentang langkah pencegahan virus COVID-19, cara menggunakan masker dengan baik dan benar dan penjelasan mengenai akan bahaya dari virus COVID-19. Penempelan posterditempatkan pada tempat yang biasannya sering dilewati oleh warga agar mudah nya arga mengetahui informasi yang disampaikan.

\section{KESIMPULAN DAN SARAN}

\section{Kesimpulan}

Peran Akuntansi tentu sangatlah berbagai macam, namun pada artikel saat ini peran akuntansi yang dimaksud adalah memberikan edukasi mengenai usaha mandiri (home industry) kepada ibu-ibu PKK. Berdasarkan hasil yang telah saya lakukan, ibu-ibu tentu mendapatkan manfaat akan edukasi dan juga materi yang telah saya berikan dari kegiatan tersebut. Usaha mandiri tentu dapat memperbaiki perekonomian ibu-ibu PKK Dusun Ambeng-Ambeng, dengan usaha kreatif rumahan (home industry) . Memberikan tambahan pendapatan tidak saja bagi pekerja atau kepentingan keluarga, tetapi juga anggota anggota keluarga lain dan mampu memproduksi barang-barang keperluan penduduk setempat dan daerah sekitarnya secara lebih efisien dan lebih murah dibanding industri besar.

\section{Saran}

a) Diharapkan ibu-ibu PKK Dusun Ambeng-Ambeng mempunyai semangat tinggi atau keinginan untuk membuka usaha mandiri (home industry) kemudian hari.

b) Diharapkan ibu-ibu PKK Dusun Ambeng-Ambeng yang sudah memiliki usahasemoga dapat menyelesaikan permasalahan dalam usahanya dengan baik.

c) Diharapkan masyarakat Dusun Ambeng-Ambeng tetap menerapkan protocol kesehatan dengan baik dan mengikuti anjuran pemerintah dengan baik dan benar.

d) Kapada mahasiswa KKN selanjutnya disarankan agar; Program Peningkatan Kualitas Ekonomi dengan Membuka Usaha Secara Mandiri (Home Industry), tetap dilanjutkan untuk mewujudkan perekonomian masyarakat desa yang lebih baik lagi. 


\section{DedikasiMU (Journal of Community Service)}

\section{Volume 4, Nomor 1, Maret 2022}

\section{DAFTAR PUSTAKA}

Sukirno, Sadono. 2011. Makro Ekonomi Teori Pengantar Edisi Ketiga. Rajawali. Pers, Jakarta.

Faisal Basri dan Haris Munandar. 2010. Dasar-dasar Ekonomi Internasional:Pengenalan \& Aplikasi Metode Kuantitatif. Jakarta: Kencana https:// www.who.int, 2020a. www.bbc.co.uk.,n.d. https://www.who.int,2020b 